\title{
"Exploring customer intentions to adopt mobile banking services: evidence from a developing country"
}

\begin{tabular}{|c|c|}
\hline \multirow{5}{*}{ AUTHORS } & Ayeasha Akhter (D) http://orcid.org/0000-0002-8128-0707 \\
\hline & Ahmed Al Asheq (D https://orcid.org/0000-0001-8281-9594 \\
\hline & R https://publons.com/researcher/3957995/ahmed-al-asheq/ \\
\hline & Md. Uzzal Hossain (D https://orcid.org/0000-0001-7596-3408 \\
\hline & Md. Mobarak Karim (D) http://orcid.org/0000-0002-0052-8716 \\
\hline ARTICLE INFO & $\begin{array}{l}\text { Ayeasha Akhter, Ahmed Al Asheq, Md. Uzzal Hossain and Md. Mobarak Karim } \\
(2020) \text {. Exploring customer intentions to adopt mobile banking services: } \\
\text { evidence from a developing country. Banks and Bank Systems, 15(2), 105-116. } \\
\text { doi:10.21511/bbs.15(2).2020.10 }\end{array}$ \\
\hline DOI & http://dx.doi.org/10.21511/bbs.15(2).2020.10 \\
\hline RELEASED ON & Tuesday, 19 May 2020 \\
\hline RECEIVED ON & Monday, 09 March 2020 \\
\hline \multirow[t]{2}{*}{ ACCEPTED ON } & Monday, 27 April 2020 \\
\hline & $(\mathrm{oc}) \mathrm{EY}$ \\
\hline LICENSE & $\begin{array}{l}\text { This work is licensed under a Creative Commons Attribution } 4.0 \text { International } \\
\text { License }\end{array}$ \\
\hline JOURNAL & "Banks and Bank Systems" \\
\hline ISSN PRINT & $1816-7403$ \\
\hline ISSN ONLINE & $1991-7074$ \\
\hline PUBLISHER & LLC "Consulting Publishing Company "Business Perspectives" \\
\hline FOUNDER & LLC "Consulting Publishing Company "Business Perspectives" \\
\hline
\end{tabular}

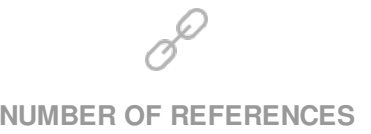

43

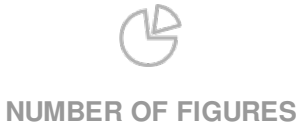

1
NUMBER OF TABLES

4

(C) The author(s) 2021. This publication is an open access article. 


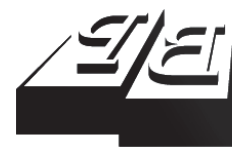

\section{BUSINESS PERSPECTIVES}

()

LLC "CPC "Business Perspectives"

Hryhorii Skovoroda lane, 10, Sumy, 40022, Ukraine

www.businessperspectives.org
Received on: $9^{\text {th }}$ of March, 2020 Accepted on: 27 $7^{\text {th }}$ of April, 2020 Published on: $19^{\text {th }}$ of May, 2020

(C) Ayeasha Akhter, Ahmed Al Asheq, Md. Uzzal Hossain, Md. Mobarak Karim, 2020

Ayeasha Akhter, Lecturer, Department of Marketing, Bangabandhu Sheikh Mujibur Rahman Science \& Technology University, Gopalganj, Bangladesh.

Ahmed Al Asheq, Lecturer, World School of Business, World University of Bangladesh, Bangladesh. (Corresponding author)

Md. Uzzal Hossain, Assistant Professor Department of Management Studies, Bangabandhu Sheikh Mujibur Rahman Science \& Technology University, Gopalganj, Bangladesh.

Md. Mobarak Karim, Assistant Professor, World School of Business, World University of Bangladesh, Bangladesh.

Ayeasha Akhter (Bangladesh), Ahmed Al Asheq (Bangladesh),

Md. Uzzal Hossain (Bangladesh), Md. Mobarak Karim (Bangladesh)

EXPLORING CUSTOMER

INTENTIONS TO ADOPT MOBILE

BANKING SERVICES: EVIDENCE FROM A DEVELOPING COUNTRY

\begin{abstract}
As the number of smart phone users and the popularity of Internet among people are growing day by day in Bangladesh, it became necessary for Bangladeshi local banks to provide mobile banking services to their customers. Therefore, this study seeks to identify the crucial and determining factors that may affect the intention of customers to use mobile banking services. The sample size in this study is 91 , in which majority are the students of Business Studies. All respondents have mobile banking at the time of the survey. The samples in the study were mainly drawn from the private university students (i.e. Business Administration students) and faculty members, and some bank officers participated as sample respondents in this study. A non-probability random sampling method is applied, and a 5\% significance level is used to accept the hypotheses. Cronbach alpha ( $\alpha$ ) of 0.7 and above is considered to measure the reliability of the item wise variables. This study examines six variables (perceived usefulness, perceived ease of use, trust, security, perceived privacy, and technology competency) to analyze their impact on the behavioral intention of banking customers to use mobile banking services. Three variables, namely perceived usefulness, security, and technology competency, are found to be significant predictors of customers' intent to use mobile banking in Bangladesh. For analytical purposes, SPSS version 23.0 is used to test hypotheses. The paper also provides significant implications for bank managers to increase the adoption of mobile banking for their sustainability.
\end{abstract}

\section{Keywords}

JEL Classification

\section{INTRODUCTION}

Bangladesh currently ranks eighth in the world in terms of population and is considered one of the growing economic nations among Asian countries. At the same time, one of the notable changes has occurred in the lifestyle of a citizen of Bangladesh, which consists in the continuous use of a smartphone. In Bangladesh, approximately 95 percent of the population uses mobile phones because of the easy availability of mobile phones with cost-effective call rates offered by mobile operators. It can be easily perceived that banks can provide different forms of financial services in both urban and rural regions in Bangladesh through implementing mobile banking services. Even in the distant part of the country, where people are mostly financially excluded, banks have the opportunity to include those unbanked people in mobile banking services. Mobile banking service reflects a platform that provides easy and convenient access to banking transaction data, relevant financial information and news on different sorts of financial products and services, depending on customer needs. This novel platform of providing financial services is gaining popularity among Bangladeshis day by day. According to the Bangladesh Bank, 17 banks 
are permitted to offer mobile financial services (MFS) to customers, out of which BRAC Bank's 'Bkash' and Dutch Bangla Bank's 'Rocket' have been the dominant market leaders in the mobile banking services. At present, 17 of the 19 banks are granted permission to run MFS in providing services, and of these, BRAC Bank's Bkash and Dutch Bangla Bank's Rocket topped the list in service providing. According to the Bangladesh Bank's data, the total number of mobile banking services reached a peak of 53.7 million in June 2019. Of these, 27.4 million are considered active users of mobile banking in Bangladesh. This growing number of cases of using mobile banking indicates that banks need to pay more attention to providing customers with the highest quality mobile financial services.

It has been evident that the number of mobile phone users using the latest technology is growing rapidly in Bangladesh day by day. Ultimately, this will force the country's local banks to offer their customers more advanced technology-based financial services, such as mobile banking. To capture the market and to understand the customer behavior, it is salient for the financial service providers to know the significant factors that can explain and predict customer behavioral intent to use and adopt mobile banking services in Bangladesh. Moreover, because of the invention of this specific service tool, business organizations, especially banks, can easily retain their current customer base and will have the options to convert cell phone users into their bank customers. However, it is not very ordinary and easy not only to retain the existing bank customers but also to attract new customers from the banking managerial perspective. Thus, banks had an extremely important strategic task to investigate and analyze variables that would contribute to bank service user's willingness to accept the mobile banking option. Therefore, the objective of this study is to investigate the determinants that predictably affect customers' intention to use mobile banking services.

\section{LITERATURE REVIEW AND HYPOTHESES DEVELOPMENT}

In the financial sector, the emergence of information technology reflects a remarkable impact on the evolution and growth of more flexible and adjustable payment gateways, which will necessarily provide convenient financial services to bank customers (Boateng, Adam, Okoe, \& AnningDorson, 2016). This new innovative platform has changed the service providing mechanism of the commercial banks by enabling them to offer the most unique and most modern financial services to their customers (Afshan \& Sharif, 2016). For instance, thanks to the latest information technology, automated teller machines (ATMs) have appeared, which have enhanced and expedited financial transactions in the contemporary banking industry (Oluwafemi, Adesuyi, \& Abdulhamid, 2013). ATMs initiated the inception of the banking self-services period, which has been extensively followed by the emergence of the mobile financial service, such as mobile banking: a modernist era of providing considerable convenience to the commercial customers (Afshan \& Sharif, 2016).
Mobile banking has emerged as one of the states of the art and user-friendly tools of the modern banking sector, followed by the latest technology. This dynamic platform has brought the newest level of technological advancement in today's banking operational activities. Technically, the general public has greater access to their bank balance information, financial transactions, and relevant information at any moment using mobile banking. This powerful platform of mobile banking is accepted by the people because of the user suitability, convenience and technological progress (Baptista \& Oliveira, 2016; Liébana-Cabanillas, Marinkovic, de Luna, \& Kalinic, 2018). Thakur (2014) opines that mobile banking comparatively povides more convenient financial services features to its target customers than other economical ways to provide financial services via the Internet. Mobile banking offers no time and place restrictions based on locational difference. Adoption of mobile banking service is considered an essential driver in analyzing the extent of financial engagement among banking customers (Abdinoor \& Mbamba, 2017). Mobile banking has been viewed as a very latest mode of electronic banking technology, which essentially makes a financial customer directly communicate with the respective bank, along with 
providing significant and expedient access to the desired financial services using a smartphone or a mobile phone (Chawla \& Joshi, 2017). First mobile financial services allowed business customers to proceed with the payments of a different utility bill and provide necessary information regarding their bank account balance via short message service in their mobile phones (Laukkanen \& Lauronen, 2005). Nowadays, mobile banking extends new services to its customers so that customers may have access to a greater variety of financial products and services, such as the fund transfer facility, money deposits, money withdrawal and online payment execution. Technically, mobile banking is rather a special mode of internet banking, that offers more augmented and added handiness of getting instant access to financial information at any given place. The enhanced application of the mobile banking service speeds up the capability to process various financial services at the time of disruption in internet connection. In contrast, internet banking requires such uninterrupted internet connectivity to proceed with financial transactions.

Mobile banking is known as one of the fastest-growing components of mobile financial services, which have already been adopted and implemented by new generation banks and other institutions providing financial services across the world (Haider, Changchun, Akram, \& Hussain, 2018). Mobile banking has been widely regarded as one of the valuable and powerful financial electronic commerce-based applications on a global scale (Baptista \& Oliveira, 2016; Malaquias \& Hwang, 2016; Chaouali, Souiden, \& Ladhari, 2017). Recently, priority is given to mobile banking by financial policymakers, and the development and implementation of the newest tool continue (Toplin, 2018). Because of the quick surge in the usage of smart mobile phones, financial institutions, such as banks, have redesigned their market competitiveness through shifting their branch's operation toward internet-driven financial service offerings (i.e. introduction of mobile banking operations) (Nasri \& Charfeddine, 2012). Mobile banking offers a wide range of service offerings, including balance checking, surfing financial records, transferring fund, paying utility bills, trading stocks, and managing portfolio (Haider, Changchun, Akram, \& Hussain, 2018).
Mobile banking can be described as "any product or service offered by a bank or a microfinance institute for conducting financial and non-financial transactions using a mobile device, namely a mobile phone, Smartphone, or Tablet" (Shaikh \& Karjaluoto, 2015). This kind of the banking channel importantly provides remarkable progress in the field of banking operations that integrate mobile technologies with financial services. Several commercial channels generally offer this service, among which, the mostly accepted mediums are a short message system and a reciprocal voice feedback mode (Shankar \& Datta, 2018).

This study develops hypotheses based on the extensive literature review, which is followed by building the productive relationship between independent and dependent variables (i.e. behavioral intention to adopt and use mobile banking). Therefore, the rest of this study has been structured in the way that the following sections discuss each of the independent variables, their causal relationship with intention to use an m-banking service. Then the next phase analyzes the study results with providing impactful managerial implications for the financial service providers. Also, there is a section that outlines concluding remarks of the research findings.

\subsection{Perceived Usefulness (PU)}

The concept of perceived usefulness (PU) can be depicted as the potential customers' extent to which a mechanism is seen to be useful to enhance their job performance (Venkatesh, Morris, G. Davis, \& F. Davis, 2003). This study has not examined the perceived usefulness construct from the organizational settings. Instead, this construct is defined as the consumers' extent to which mobile banking is perceived beneficially useful to meet up the desired needs and wants of mobile banking users. According to Mutahar, Daud, Thurasamy, Isaac, and Abdulsalam (2018), perceived usefulness works as a more differential variable towards mobile banking customers than that of non-mobile bankers. Prior research found that perceived value is evidenced to saliently affect customers' behavioral propensity (Venkatesh et al., 2003). Several previous researchers validated that higher level of PU would significantly trigger consumer's behavioral willingness (Raza, Umer, \& Shah, 2017). The 
study completed by Al Khasawneh (2015) showed that a more significant degree of perceived usefulness would necessarily contribute to a higher level of adoption of mobile financial services by mobile phone users. Therefore, it is assumed that perceived usefulness (PU) of mobile banking will positively affect the intention of users to use and adopt mobile banking. Hence, the following hypothesis is proposed:

\section{H1: $\quad$ Perceived usefulness (PU) of mobile banking affects customers' intent to use mobile bank- ing services.}

\subsection{Perceived Ease of Use (PEU)}

Davis, Bagozzi, and Warshaw (1989) state that the perceived ease of use (PEU) potentially demonstrates the extent of user expectations about a target mechanism that will be effortless. Agarwal and Karahanna (2000) explained this construct as crucial in describing a person's reaction to any distinct technology. It is argued that technological aspects in designing mobile banking service need to be understandable and user-friendly for the targeted customers so that they could quickly adapt and embrace the service (Koksal, 2016). In the service apps of the mobile financial banking system, several features might cause some complexities, namely complicated navigation process, the tiny size of the mobile screen, and some inconvenience in the transaction portfolio. If the functional operations of mobile banking are found to be uncomplicated and straightforward for usage purposes, then it shall impact the customers' usage. The construct measure is elucidated as the extent to which the potential banking customers assume the service system to be painless and effortless (Venkatesh et al., 2003). According to AlSoufi and Ali (2014), this variable (PEU) plays a pivotal and decisive role in determining a person's reaction to information technology. Past studies provide necessary evidence about the substantial effect of PEU on people's usage propensity (Venkatesh et al., 2003). Azad (2016) revealed that PEU is found to be the most effective determinant of consumer's willingness to accept and embrace mobile banking. Therefore, based on the extensive literature review, the following hypothesis is proposed:

H2: Perceived ease of use (PEU) affects customers' intention to use mobile banking.

\subsection{Trust (TR)}

The idea of trust (TR) can be attributed to a person's judgment regarding a precise form of service, which may continuously meet expectations, and it necessarily reflects people's personal likelihood to relentlessly depend on a specific function and its associated features (Koksal, 2016). Trust is built on the following three distinguishable aspects:

a) the potentiality of a particular service to execute necessary tasks in time;

b) the capability to attain its claims without deception; and

c) the sincerity to think of customer's wants in a timely manner (Azad, 2016).

It is extremely important to develop a trust mechanism as it does reduce the degree of customer's negative perception, dubiety and confusion, through which the adoption propensity among individuals will increase over time (Koksal, 2016). The measure of trust is considered a critical construct in the context of emerging self-service technologies; since these technological advancements may have a dearth in maintaining proper personal interaction, which is integrated with financial issues that can turn out to be delicate (Alalwan, Dwivedi, Rana, Lal, \& Williams, 2015). In the field of mobile banking, individual connection and interactivity have remained a vital concern for facilitating customer loyalty purposes; since when an adequate level of personal interaction may remain missing in the service portal, then customers' switching intention might also increase (Farah, 2018). Sahoo and Pillai (2017) conducted a study to measure mobile banking usage intention and found that in respect of the mobile banking service, the level of personal trust will enhance the perception about the security system of the service application. These variables are viewed as primary determinants of customers' gratification. Mainly, customers' knowledge about the trust may reinforce the advantages and values of the mobile banking service, through diminishing the personal concern level (Alalwan, Dwivedi, Rana, \& Williams, 2016). Therefore, trust plays a pivotal role in creating an increased level of adoption of mobile banking through reducing concern is- 
sues of safety and fraudulent related dangers in the technology-based mobile banking atmosphere (Afshan \& Sharif, 2016). Furthermore, customer trust is considered one of the critical factors in examining and evaluating the growth and flourishing of mobile banking (Al Khasawneh, 2015). Hence, it is hypothesized that:

\section{H3: Trust (TR) positively affects customers' in- tention to adopt mobile banking.}

\subsection{Perceived Security (PSec)}

Kalakota and Whinston (1997) explicated the term "security" as a prospective form of threat that originates an environment, a situation or a frame of an event with a chance to create financial risk to the data or network, which would cause destruction, restriction or tampering of the database. Perceived security (PSec) in the electronic commerce platform ensures data protection so that users will enjoy threat free shopping experience in online business platforms (Yenisey, Ozok, \& Salvendy, 2007). On the other hand, Merhi, Hone, and Tarhini (2019) illustrated the measure of perceived security (PSec) as a matter of individual possibility, through which targeted customers are convinced that information will not be contaminated, engineered or exposed to other parties as a means of future exploitation. This measure has been extensively explored in some past studies. Security is perceived as a pressing concern at the period of performing financial transactions in either online or electronic channels. Hence, PSec could be a severe obstacle to the acceptance of mobile banking, since there is a threat of revealing the critical financial information by the other fraudulent parties. The security process of any mobile banking application is found to have a positive influence on the individual's willingness and inclination to use (Changchit, Lonkani, \& Sampet, 2017). Hence, it is hypothesized that:

H4: Perceived security (PSec) has a positive impact on behavioral intentions to use mobile banking.

\subsection{Perceived Privacy (PPR)}

The idea of privacy can be explained as the perceived form of safety people usually obtain regarding the gathering, preserving, and transmitting of their information (Forcht, 1994). Namahoot and Laohavichien (2018) described perceived privacy (PPR) as an individual's point of view that business firms collect crucial data about them, as well as the unlawful usage of gathered data. The responsibility of protecting and conserving the customers' data in a more private and secured way lies with business organizations. Privacy has remained a massive concern for the development of online business growth. It is argued that customers' inclination to shop online intensively relies on the degree of privacy they have control over the online platform (Sreejesh, Anusree, \& Mitra, 2016). Moreover, users' propensity to engage in online financial activities is determined by their perception of privacy regarding the online system (Zorotheos \& Kafeza, 2009). The following hypothesis is put forward:

H5: Perceived privacy (PPR) affects the customer's intention to use mobile banking.

\subsection{Technology Competency (TC)}

Technology competency (TC) is explicated as the degree to which a person is well learned about how to efficiently leverage the medium of information technology to handle and organize the information (Tippins \& Sohi, 2003). Commonly, customers who possess a greater extent of self-confidence are more inclined to accept and embrace technological applications and services. Also, this type of customers exhibits a higher level of the optimistic perspective and propensity to take and use technological products and services than the people who have a lower level of confidence about technology. On that account, customers with a higher degree of technology competency (TR) have been expected to possess an optimistic viewpoint and inclinations to use mobile banking. Importantly, a higher level of technology competency enables mobile users to conceive that mobile banking will be more convenient and easier for them to operate and transact with (Yang, 2010). Hence, the following hypothesis is assumed:

H6: Technology competency (TC) does influence the customer's intention to use mobile banking.

Therefore, this study develops the following six hypotheses to measure the customer's willingness to use and adopt mobile banking services: 


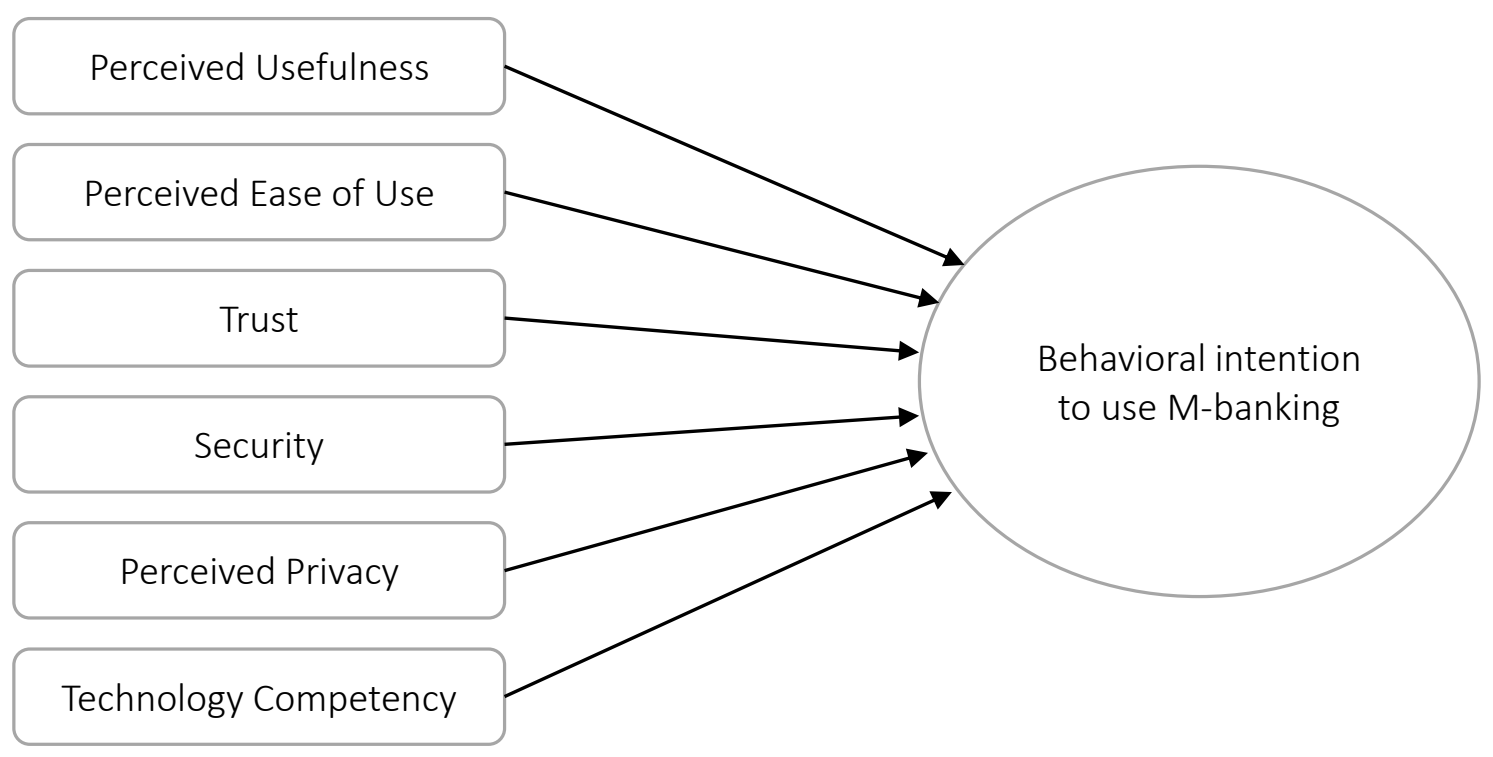

Figure 1. Conceptual framework of the study

H1: Perceived usefulness (PU) of mobile banking affects customers' intent to use mobile banking services.

H2: Perceived ease of use (PEU) affects customers' intention to use mobile banking.

H3: Trust (TR) positively affects customers' intent to adopt mobile banking.

H4: Perceived security (PSec) has a positive impact on behavioral intentions to use mobile banking.

H5: Perceived privacy (PPR) affects the customer's intention to use mobile banking.

H6: Technology competency (TC) does influence the customer's intention to use mobile banking.
Based on these hypotheses, the following model is proposed (Figure 1)

\section{METHODOLOGY}

The study was quantitative and exploratory in nature. It exclusively used only primary data. For the data collection purpose, the study has applied a non-probability random sampling technique. The survey questionnaire was randomly distributed among those respondents who were assumed to have any form of a bank or mobile banking account. First, the questionnaire asked the respondents whether they have any mobile bank accounts or not. If the answer was negative, then the survey stopped and approached another respondent. A total of 120 respondents were distributed to fill out an online survey form. And, in turn, 91 responses were found valid, reflecting the $75 \%$ response

Table 1. References to the sources of accepted questionnaires

\begin{tabular}{l|c}
\hline \multicolumn{1}{c}{ Variable } & Source \\
\hline Perceived Usefulness (measured by four items) & \\
Perceived Ease of use (measured by three items) & Changchit, Klaus, Lonkani, and Sampet (2019) \\
Perceived Security (measured by four items) & \\
Trust (measured by three items) & Farah, Hasni, and Abbas (2018) \\
\hline Technology Competence (measured by three items) & \\
\hline Trust (measured by three items) & \\
\hline Behavioral Intention & \\
\hline
\end{tabular}


Table 2. Item wise of the Cronbach Alpha ( $\boldsymbol{\alpha})$ value

\begin{tabular}{|c|c|c|}
\hline & Variable & Overall $\alpha$ \\
\hline \multicolumn{3}{|c|}{ Behavioral Intention (BI) } \\
\hline $\mathrm{BI} 1$ & I intend to continue using mobile banking in the future & \multirow{3}{*}{.830} \\
\hline $\mathrm{B} 12$ & I will always try to use mobile banking in my daily life & \\
\hline $\mathrm{BI} 3$ & I plan to continue to use mobile banking frequently & \\
\hline \multicolumn{3}{|c|}{ Perceived Usefulness (PU) } \\
\hline PU1 & It is less time consuming than doing transactions at bank sites & \multirow{4}{*}{.783} \\
\hline PU2 & I usually get a faster service than doing transactions at bank sites & \\
\hline PU3 & Mobile banking allows me to do transactions at any time & \\
\hline PU4 & Mobile banking allows me to do transactions at my own pace & \\
\hline \multicolumn{3}{|c|}{ Perceived Ease of Use (PEU) } \\
\hline PEU1 & Learning to use mobile banking is easy for me & \multirow{3}{*}{.749} \\
\hline PEU2 & I find it easy to get mobile banking to do what I want for my banking purposes & \\
\hline PEU3 & My interaction with mobile banking is clear and understandable & \\
\hline \multicolumn{3}{|c|}{ Trust (TR) } \\
\hline TR1 & I believe that mobile banking is trustworthy & \multirow{3}{*}{.752} \\
\hline TR2 & I believe that mobile banking keeps its promises & \\
\hline TR3 & I believe that mobile banking keeps users' interest in mind & \\
\hline \multicolumn{3}{|c|}{ Perceived Security (PSec) } \\
\hline PSec1 & Using Internet banking makes me believe that the existing regulations are sufficient to ensure that users are protected & \multirow{4}{*}{.829} \\
\hline PSec 2 & Overall, I am not worried about the security of the mobile banking & \\
\hline PSec 3 & I believe that my banks protect me from unauthorized charges & \\
\hline PSec 4 & I believe that my transactions are secured & \\
\hline \multicolumn{3}{|c|}{ Perceived Privacy (PPR) } \\
\hline PPR1 & I believe that the mobile banking system will protect the privacy of my personal banking data & \multirow{3}{*}{.921} \\
\hline PPR2 & I believe that the mobile banking systems will not disclose my personal banking data & \\
\hline PPR3 & I enjoy working with technology & \\
\hline \multicolumn{3}{|c|}{ Technology Competency (TC) } \\
\hline TC1 & My ability to learn new technology is high & \multirow{3}{*}{.751} \\
\hline TC2 & I am always interested in new technology & \\
\hline TC3 & I enjoy working with technology & \\
\hline
\end{tabular}

rate. The online survey questionnaire was self-administered in nature. Respondents were contacted through emails and several mobile calls. The variable wise questionnaires in this study have been taken from past studies. Table 1 exhibits the sources of accepted questionnaires.

The survey questionnaire has two parts. The first part includes demographic information of the respondents (such as gender, age, educational level, and the relationship with a bank). The second part consists of the item-wise questionnaire on behavioral intention, perceived usefulness, perceived ease of use, trust, security, privacy and technology competence. An item-wise question is measured on a 5-point Likert scale, where ' 1 ' stands for 'Strongly Disagree' and ' 5 ' stands for 'Strongly Agree'. To measure the internal consistency of each variable, the 0.70 score of Cronbach's coefficient (Alpha) is considered as reliable in the study. Each variable is found reliable, since each of them has the reliability score of above 0.70 . Table 2 shows the item wise of the Cronbach's coefficient (Alpha) for each variable.

This study has chosen SPSS version 23.0 for data analysis. Hypotheses are tested using SPSS where the $5 \%$ significance level is considered to accept inferences.

\section{RESULTS}

This study seeks to assess the impact of perceived usefulness, perceived ease of use, trust, security, privacy and technology competence on the customer's behavioral intention to use mobile banking in Bangladesh. The survey respondents were drawn 
from private universities through the personal snowball sampling technique. On a special note, BBA and MBA students and private university's faculty members participated in this survey, while several bank officers also participated as respondents. Out of distributed 120 survey questionnaires, 91 respondents participated in the study. Among them, $29 \%$ were male and $71 \%$ were female respondents. $85 \%$ of the respondent's age was between 18-30 years, while $14 \%$ was between $31-40$ years. Only one respondent's age was reported more than 40 years of age (1.1\%). $40 \%$ of respondents were master's degree holder, while $48 \%$ were undergraduates. Only $11 \%$ of the respondents have completed their study of up to HSC level. $42 \%$ of the respondents have more than 5-year relationship with a bank, while $35 \%$ have $1-5$ years. Sample characteristics of demographic information are shown in Table 3.

Table 3. Sample characteristics

\begin{tabular}{|c|c|c|}
\hline Characteristic & $\begin{array}{l}\text { Number } \\
(n=91)\end{array}$ & Percentage (\%) \\
\hline \multicolumn{3}{|c|}{ Gender } \\
\hline Female & 26 & $28.6 \%$ \\
\hline Male & 65 & $71.4 \%$ \\
\hline \multicolumn{3}{|c|}{ Age } \\
\hline $18-30$ & 77 & $84.6 \%$ \\
\hline $31-40$ & 13 & $14.3 \%$ \\
\hline $41-50$ & 1 & $1.1 \%$ \\
\hline \multicolumn{3}{|c|}{ Educational level } \\
\hline M.Phil./Ph.D. & 1 & $1.1 \%$ \\
\hline Master & 36 & $39.6 \%$ \\
\hline $\begin{array}{l}\text { Undergraduate/Bachelor } \\
\text { degree }\end{array}$ & 44 & $48.4 \%$ \\
\hline Up to HSC & 10 & $11.0 \%$ \\
\hline \multicolumn{3}{|c|}{ Relationship with bank } \\
\hline $1-5$ years & 32 & $35.2 \%$ \\
\hline Above 5 years & 38 & $41.8 \%$ \\
\hline Less than 1 year & 21 & $23.1 \%$ \\
\hline
\end{tabular}

Table 2 shows that the Cronbach ( $\alpha$ ) value of behavioral intention $(B I)$ is 0.83 , which is well accepted, and the item is reliable. The a score of the ' $P U$ ' item is 0.783 , and the item is accepted as reliable. The Cronbach coefficient value of the ' $P E U$ ' item is reliable $(\alpha=0.749)$. The other three items, 'TR' $(\alpha=0.752)$, 'PSec' $(\alpha=0.829)$ and 'PPR' ( $\alpha$ $=0.921$ ), are also confirmed as reliable measures, since their Cronbach coefficient values are above 0.70 . Therefore, all the study variables were confirmed as a reliable measure, as their Cronbach coefficient values ( $\alpha$ ) exceed the statistical threshold value of 0.70 . The statistical literature has revealed that some studies have adopted different significance levels (different $p$ values) to accept or reject the hypotheses. This study adopted a $5 \%$ significance level $(p=0.05)$ to accept the hypotheses, since many studies followed the significance level. Table 4 shows that the ' $\mathrm{R}^{2}$ Change' value is 0.6222 , which does mean that the study model essentially explains the $62.2 \%$ variation to predict customer intent to use mobile banking. The study model is free from multicollinearity problem as the variance inflation factor (VIF) values of all variables are less than 5 ; also, the tolerance value lies in between 0.1 to 1.0 for all variables. Thus, no multicollinearity is reported in the study model.

\section{DISCUSSION}

According to Table 4, the hypothesis is accepted if the $p$-value is less than $5 \%$ or 0.05 . $H 1$ states that perceived usefulness will impact customer intention to use mobile banking. The hypothesis is accepted at the $5 \%$ significance level $(\beta=0.269 ; p$ $<0.05)$. That means that a higher level of use of mobile banking service will influence more rate of customer usage and adoption of the service. The

Table 4. Results of the coefficient value (regression analysis)

\begin{tabular}{|c|c|c|c|c|c|}
\hline Variable & $B$-value & $t$-value & $p$-value & Tolerance & VIF \\
\hline Perceived Usefulness & .269 & 3.407 & .001 & .720 & 1.389 \\
\hline Perceived Ease of Use & .155 & 1.442 & .153 & .390 & 2.562 \\
\hline Trust & -.086 & -.898 & .372 & .489 & 2.047 \\
\hline Perceived Security & .416 & 5.534 & .000 & .797 & 1.254 \\
\hline Perceived Privacy & .106 & 1.065 & .290 & .454 & 2.203 \\
\hline Technology Competency & .286 & 3.855 & .000 & .816 & 1.226 \\
\hline
\end{tabular}

Note: ${ }^{*} p<0.05 ; * *<0.01(n=91) ; R^{2}$ Change $=0.622$. 
result is in line with the previous studies. Wessels and Drennan (2010) found perceived usefulness as one of the determinants of customer intent to use mobile banking. It does signify that the sample of this research demonstrated that if the customers find mobile banking useful, then they will increasingly adopt this service.

According to the regression result, $\mathrm{H} 2$ is rejected at $5 \%(\beta=0.1555 ; p>0.05)$. It does mean that the perceived ease of use may or may not influence the user's intent to use mobile banking. The reason can be that sometimes, users may not find the ease of use relevant, rather they focus on other aspects of the service application. Trust is predicted to influence customer intent to use mobile banking (H3), and this hypothesis is also rejected at $5 \%$ (see Table 4). Perhaps, mobile banking users have been least concerned about the trust issue in the local context, as mobile banking service providers in Bangladesh are interconnected with the banking sectors, and people have the confidence in the banking sector. $H 4$ states that security affects the intention to use mobile banking; thus $\mathrm{H} 4$ is accepted at $5 \%(\beta=0.416 ; p<0.05)$, implying that a high level of security of the mobile banking service will induce a higher number of customers to use mobile banking. Singh and Srivastava (2018) find that privacy has a significant impact on the customers' intent to use mobile banking. Perceived privacy is reported as the insignificant independent variable in this study as $\mathrm{H5}$ is rejected at $5 \%$, meaning that privacy may not affect behavioral intent to use mobile banking. Technology competency (H6) is hypothesized to influence customer behavioral intent to use mobile banking, and this is also accepted at 5\% $(\beta=0.286 ; p<0.05)$. It does imply that a higher level of technology competency will lead to a higher number of customer's willingness to use mobile banking service. The result is consistent with the prior research (Oliveira, Faria, Thomas, \& Popovič, 2014).

\section{IMPLICATIONS}

In this study, three variables are found as significant, as they can predict the customers' behavioral intent to use and adopt mobile banking in Bangladesh. Since perceived usefulness has a positive effect in explaining behavioral intent to use and adopt mobile banking, it has become more imperative for the service providers. It ensures that their provided mobile banking services need to be more user-friendly, timely, uncomplicated and flexible in comparison with conventional financial services. Mobile banking providers are expected to be more aware of the security system of their services in Bangladesh. It necessarily implies that mobile banking services need to be critically designed in such a way to ensure the highest degree of security among the consumers so that it will stimulate consumers to adopt this service. Moreover, mobile banking providers should keep in their mind when designing a service that mobile banking should be technology-friendly for consumers. Hence, service providers should tailor their different kinds of marketing and promotional strategies to make consumers learn the operation of their provided services, since technological competency will vary from person to person. Exclusive attention needs to be paid to those consumers who are not technically sound. In addition, it would be advantageous for banking and non-banking institutions to invest in the development of viable security measures for their mobile banking services in order to achieve greater customer acceptance.

\section{CONCLUSION}

In conclusion, since many financial institutions have already introduced and implemented mobile banking services to increase their customer base and provide more handful financial solutions to remain more competitive in the industry, the growth and development of mobile banking have been intensively correlated with the acceptance of this service by customers. Thus, the study is important for the Bangladeshi banking industry, as it facilitates outstanding and insightful practical contributions. The study aims to examine the determinants of customers' behavioral intention to use mobile banking in Bangladesh. Out of six variables, three variables, namely perceived usefulness, security, and technology 
competency, were identified as important predictors of the behavioral intention of customers to use mobile banking services in Bangladesh. Although perceived ease of use, trust and perceived privacy do not play any significant role in explaining behavioral intentions, mobile banking service providers will consider these factors to make their mobile banking services more competitive in the market. Importantly, realizing and considering variables that may affect customers' intention to adopt mobile banking will certainly help financial institutions that provide services to more effectively develop their organizational goals to accelerate customers' willingness to accept and embrace this novel mobile banking service.

\section{AUTHOR CONTRIBUTIONS}

Conceptualization: Ayeasha Akhter, Ahmed Al Asheq.

Data curation: Md. Uzzal Hossain, Md. Mobarak Karim.

Formal analysis: Ayeasha Akhter, Ahmed Al Asheq, Md. Uzzal Hossain, Md. Mobarak Karim.

Funding acquisition: Ayeasha Akhter, Md. Uzzal Hossain, Md. Mobarak Karim.

Methodology: Ayeasha Akhter, Ahmed Al Asheq, Md. Uzzal Hossain.

Project administration: Ayeasha Akhter, Md. Uzzal Hossain, Md. Mobarak Karim.

Resources: Ayeasha Akhter, Md. Uzzal Hossain, Md. Mobarak Karim.

Software: Ahmed Al Asheq, Md. Uzzal Hossain, Md. Mobarak Karim.

Supervision: Ahmed Al Asheq, Md. Uzzal Hossain.

Validation: Ayeasha Akhter, Ahmed Al Asheq, Md. Mobarak Karim.

Visualization: Ayeasha Akhter, Md. Uzzal Hossain, Md. Mobarak Karim.

Writing - original draft: Ayeasha Akhter, Ahmed Al Asheq.

Writing - reviewing \& editing: Ayeasha Akhter, Ahmed Al Asheq, Md. Uzzal Hossain.

\section{REFERENCES}

1. Abdinoor, A., \& Mbamba, U. O. (2017). Factors influencing consumers' adoption of mobile financial services in Tanzania. Cogent Business \& Management, 4(1), 1392273. https://doi.org/10. 1080/23311975.2017.1392273

2. Afshan, S., \& Sharif, A. (2016). Acceptance of mobile banking framework in Pakistan.

Telematics and Informatics, 33(2), 370-387. https://doi. org/10.1016/j.tele.2015.09.005

3. Agarwal, R., \& Karahanna, E. (2000). Time flies when you're having fun: Cognitive absorption and beliefs about information technology usage. MIS Quarterly, 24(4), 665-694. https://doi. org/10.2307/3250951

4. Al Khasawneh, M. H. (2015). An empirical examination of consumer adoption of mobile banking (M-Banking) in Jordan. Journal of Internet Commerce, 14(3), 341-362. https://doi.org/10 $.1080 / 15332861.2015 .1045288$
5. Alalwan, A. A., Dwivedi, Y. K., Rana, N. P., \& Williams, M. D. (2016). Consumer adoption of mobile banking in Jordan: examining the role of usefulness, ease of use, perceived risk and self-efficacy. Journal of Enterprise Information Management, 29(1), 118-139. https://doi.org/10.1108/ JEIM-04-2015-0035

6. Alalwan, A. A., Dwivedi, Y. K., Rana, N. P., Lal, B., \& Williams, M. D. (2015). Consumer adoption of Internet banking in Jordan: Examining the role of hedonic motivation, habit, self-efficacy and trust. Journal of Financial Services Marketing, 20(2), 145-157. http:// doi.org/10.1057/fsm.2015.5

7. AlSoufi, A., \& Ali, H. (2014). Customer's perception of $\mathrm{m}$-banking adoption in of Bahrain: an empirical assessment of an extended TAM model. International Journal of Managing Information Technology, 6(1), 1-13. Retrieved from https:// arxiv.org/ftp/arxiv/papers/1403/1403.2828.pdf
8. Azad, M. A. K. (2016). Predicting mobile banking adoption in Bangladesh: a neural network approach. Transnational Corporations Review, 8(3), 207214. https://doi.org/10.1080/19186 444.2016.1233726

9. Baptista, G., \& Oliveira, T. (2016) A weight and a meta-analysis on mobile banking acceptance research. Computers in Human Behavior, 63, 480-489. https://doi. org/10.1016/j.chb.2016.05.074

10. Boateng, H., Adam, D. R., Okoe, A. F., \& Anning-Dorson, T. (2016). Assessing the determinants of internet banking adoption intentions: A social cognitive theory perspective. Computers in Human Behavior, 65, 468478. https://doi.org/10.1016/j. chb.2016.09.017

11. Changchit, C., Klaus, T., Lonkani, R., \& Sampet, J. (2019). A Cultural Comparative Study of Mobile Banking Adoption Factors. Journal of Computer Information Systems, 1-11. https://doi.org/10.1 080/08874417.2018.1541724 
12. Changchit, C., Lonkani, R., \& Sampet, J. (2017). Mobile banking: Exploring determinants of its adoption. Journal of Organizational Computing and Electronic Commerce, 27(3), 239261. https://doi.org/10.1080/10919 392.2017.1332145

13. Chaouali, W., Souiden, N., \& Ladhari, R. (2017). Explaining adoption of mobile banking with the theory of trying, general selfconfidence, and cynicism. Journal of Retailing and Consumer Services, 35, 57-67. https://doi.org/10.1016/j. jretconser.2016.11.009

14. Chawla, D., \& Joshi, H. (2017). Consumer perspectives about mobile banking adoption in India-a cluster analysis. International Journal of Bank Marketing, 35(4), 616-636. https:// doi.org/10.1108/IJBM-03-20160037

15. Davis, F. D., Bagozzi, R. P., \& Warshaw, P. R. (1989). User acceptance of computer technology: a comparison of two theoretical models. Management Science, 35(8), 982-1003. https:// doi.org/10.1287/mnsc.35.8.982

16. Farah, M. F., Hasni, M. J. S., \& Abbas, A. K. (2018). Mobilebanking adoption: empirical evidence from the banking sector in Pakistan. International Journal of Bank Marketing, 36(7), 13861413. https://doi.org/10.1108/ IJBM-10-2017-0215

17. Forcht, K. A. (1994). Computer Security Management. Course Technology Press.

18. Haider, M. J., Changchun, G., Akram, T., \& Hussain, S. T. (2018). Does gender differences play any role in intention to adopt Islamic mobile banking in Pakistan? An empirical study. Journal of Islamic Marketing, 9(2), 439-460. https:// doi.org/10.1108/JIMA-11-20160082

19. Kalakota, R., \& Whinston, A. B. (1997). Electronic commerce: $a$ manager's guide. Addison-Wesley Professional.

20. Koksal, M. H. (2016). The intentions of Lebanese consumers to adopt mobile banking.
International Journal of Bank Marketing, 34(3), 327-346. https:// doi.org/10.1108/IJBM-03-20150025

21. Laukkanen, T., \& Lauronen, J. (2005). Consumer value creation in mobile banking services. International Journal of Mobile Communications, 3(4), 325338. https://doi.org/10.1504/ IJMC.2005.007021

22. Liébana-Cabanillas, F., Marinkovic, V., de Luna, I. R., \& Kalinic, Z. (2018). Predicting the determinants of mobile payment acceptance: A hybrid SEM-neural network approach. Technological Forecasting and Social Change, 129, 117-130. https://doi.org/10.1016/j. techfore.2017.12.015

23. Malaquias, R. F., \& Hwang, Y. (2016). An empirical study on trust in mobile banking: A developing country perspective. Computers in Human Behavior, 54, 453-461. https://doi.org/10.1016/j. chb.2015.08.039

24. Merhi, M., Hone, K., \& Tarhini, A. (2019). A cross-cultural study of the intention to use mobile banking between Lebanese and British consumers: Extending UTAUT2 with security, privacy and trust. Technology in Society, 59, 101151. https://doi.org/10.1016/j. techsoc.2019.101151

25. Mutahar, A. M., Daud, N. M., Thurasamy, R., Isaac, O., \& Abdulsalam, R. (2018). The mediating of perceived usefulness and perceived ease of use: the case of mobile banking in Yemen. International Journal of Technology Diffusion (IJTD), 9(2), 21-40. https://doi.org/10.4018/ IJTD.2018040102

26. Namahoot, K. S., \& Laohavichien, T. (2018). Assessing the intentions to use internet banking: The role of perceived risk and trust as mediating factors. International Journal of Bank Marketing, 36(2), 256-276. https://doi.org/10.1108/ IJBM-11-2016-0159

27. Nasri, W., \& Charfeddine, L. (2012). Factors affecting the adoption of Internet banking in Tunisia: An integration theory of acceptance model and theory of planned behavior. The Journal of High Technology Management Research, 23(1), 1-14. https://doi. org/10.1016/j.hitech.2012.03.001

28. Oliveira, T., Faria, M., Thomas, M. A., \& Popovič, A. (2014). Extending the understanding of mobile banking adoption: When UTAUT meets TTF and ITM. International Journal of Information Management, 34(5), 689-703. https://doi.org/10.1016/j. ijinfomgt.2014.06.004

29. Oluwafemi, O., Adesuyi, F. A., \& Abdulhamid, M. (2013). Combating terrorism with cybersecurity: The Nigerian perspective. World Journal of Computer Application and Technology, 1(4), 103-109. Retrieved from https://www. semanticscholar.org/paper/ Combating-Terrorism-withCybersecurity\%3A-The-Oluwafemi-Adesuyi/8461626b08ea892c3 e31b75f33d1a215c0a5d495

30. Raza, S. A., Umer, A., \& Shah, N. (2017). New determinants of ease of use and perceived usefulness for mobile banking adoption. International Journal of Electronic Customer Relationship Management, 11(1), 44-65. https://doi.org/10.1504/ IJECRM.2017.086751

31. Sahoo, D., \& Pillai, S. S. (2017). Role of mobile banking service scape on customer attitude and engagement: An empirical investigation in India. International Journal of Bank Marketing, 35(7), 1115-1132. https://doi.org/10.1108/IJBM-092015-0144

32. Shaikh, A. A., \& Karjaluoto, H. (2015). Mobile banking adoption: A literature review. Telematics and Informatics, 32(1), 129142. https://doi.org/10.1016/j. tele.2014.05.003

33. Shankar, A., \& Datta, B. (2018). Factors affecting mobile payment adoption intention: An Indian perspective. Global Business Review, 19(3_suppl), 72-89. https://doi.org /10.1177\%2F0972150918757870

34. Singh, S., \& Srivastava, R. K. (2018). Predicting the intention 
to use mobile banking in India. International Journal of Bank Marketing, 36(2), 357-378. https:// doi.org/10.1108/IJBM-12-20160186

35. Sreejesh, S., Anusree, M. R., \& Mitra, A. (2016). Effect of information content and form on customers' attitude and transaction intention in mobile banking. International Journal of Bank Marketing, 34(7), 1092-1113. https://doi.org/10.1108/IJBM-072015-0107

36. Thakur, R. (2014). What keeps mobile banking customers loyal? International Journal of Bank Marketing, 32(7), 628-646. https:// doi.org/10.1108/IJBM-07-20130062

37. Tippins, M. J., \& Sohi, R. S. (2003). IT competency and firm performance: is organizational learning a missing link? Strategic
Management Journal, 24(8), 745-761. https://doi.org/10.1002/ smj.337

38. Toplin, J. (2018). Mobile banking is more important than ever. Business Insider. BI Intelligence. Retrieved from https://www. businessinsider.com/mobilebanking-is-more-important-thanever-2018-1

39. Venkatesh, V., Morris, M. G., Davis, G. B., \& Davis, F. D. (2003). User acceptance of information technology: Toward a unified view. MIS Quarterly, 27(3), 425-478. https://doi.org/10.2307/30036540

40. Wessels, L., \& Drennan, J. (2010). An investigation of consumer acceptance of M-banking. International Journal of Bank Marketing, 28(7), 547-568. https://doi. org/10.1108/02652321011085194
41. Yang, K. (2010). The effects of technology self-efficacy and innovativeness on consumer mobile data service adoption between American and Korean consumers. Journal of International Consumer Marketing, 22(2), 117-127. https://doi. org/10.1080/08961530903476147

42. Yenisey, M. M., Ozok, A. A., \& Salvendy, G. (2007). Perceived security determinants in e-commerce among Turkish university students. Behaviour \& Information Technology, 24(4), 259-274. https://doi.org/10.1080/0144929042000320992

43. Zorotheos, A. \& Kafeza, E. (2009) Users' perceptions on privacy and their intention to transact online: a study on Greek internet users. Direct Marketing: An International Journal, 3(2), 139-153. https://doi. org/10.1108/17505930910964795 